\title{
ORIGINAL
}

\section{Effect of BMP on the differentiation of bone marrow stromal cells into osteoblasts in a collagen-gel culture}

\author{
Yayoi Hashimoto, Hirokata Shimokobe, Morimichi Mizuno* and Yoshinori Kuboki* \\ Department of Operative Dentistry I, Hokkaido University School of Dentistry \\ (Chief : Prof. Hirokata Shimokobe) \\ *Department of Biochemistry, Hokkaido University School of Dentistry \\ (Chief : Prof. Yoshinori Kuboki) \\ K-13, W-7 Kita-ku, Sapporo 060, Japan
}

〔Received on September 30, 1994 ; Accepted on January 30, 1995〕

Key words : BMP (bone morphogenetic protein)/collagen-gel/differentiation/osteoblasts/bone marrow

\begin{abstract}
In-gel administration of recombinant BMP 2 (rBMP 2) to cultured bone marrow cells induces differentiation into osteoblasts much more efficiently than the conventional addition of rBMP 2 to the culture medium. We recently found that bone marrow cells cultured on collagen-gel could form bone-like calcified nodules within two weeks after confluence without the addition of the strong differentiationinducer dexamethasone. Using these cells on collagen-gel culture, the present study sought to evaluate the effects of rBMP 2 on cell differentiation. rBMP 2 was added to cultured rat bone marrow cells under three different conditions: (1) cells were cultured in $\alpha$-MEM with $15 \%$ fetal calf serum (standard medium) which contained various concentrations rBMP 2, (2) cells were cultured in standard medium which contained $10^{-8} \mathrm{M}$ dexamethasone (Dex), $10 \mathrm{mM} \beta$-glycerophosphate $(\beta$-GP), and $\mathrm{rBMP} 2$ at different concentrations, and (3) cells were cultured on collagen-gel which contained rBMP 2 at different concentrations. In the standard medium (condition 1), the addition of rBMP 2 did not induce the cells to differentiate to form calcified nodules within a week, although both alkaline phosphatase activity and DNA content increased in a dose-dependent manner. In contrast, the addition of rBMP 2 as a component of collagen-gel (condition 3) markedly accelerated the phenotype expression of alkaline phosphatase and osteocalcin, as well as calcified nodule formation. This is the first report to demonstrate that collagen-gel enhances the effect of BMP in vitro. A similar effect was observed with rBMP 2 in the presence of Dex and $\beta$-GP (condition 2).
\end{abstract}

抄録：骨骮有間質細胞（骨髄細胞）は，ある条件では骨芽細胞に分化するが，われわれはこれらの細胞をコラー ゲンゲル上で培養することにより骨様石灰化結節を形成させた。本研究の目的は, この培養系を用いて細胞分化 に及ぼすリコンビナント BMP 2 (rBMP 2) の効果を評価することである。ラット骨髄細胞に対し, 以下の $3 つ$ の培養条件において rBMP 2 を添加し培養を行った。（1）15\% FCS を加えた $\alpha$-MEM（標準培地），（2）標 準培地に $10^{-8} \mathrm{M}$ デキサメサゾン (Dex), $10 \mathrm{mM} \beta$-グリセロリン酸 $(\beta-\mathrm{GP})$ を添加したもの，（3）種々の濃度の rBMP 2 を添加したコラーゲンゲル上培養。その結果, 標準培地に rBMP 2 を添加したところ ALP 活性は上昇 したが，石灰化結節の形成はみられなかった。一方コラーゲンゲルに rBMP 2 を添加すると, ALP 活性, オス テオカルシン産生，石灰化結節の形成が著明に促進された。同様の効果は Dex, $\beta$-GP の存在下でも認められた。 今回初めて, 細胞外マトリックスであるコラーゲンのゲルが BMP の効果を促進することが明らかとなった。 


\section{Introduction}

In the field of dentistry, hard tissue reconstruction is often required, from the small-scale formation of a dentin bridge in endodontics to large-scale mandibular augmentation after tumor extraction. Successful reconstructions, require systematic considerations of both biological principles and clinical problems.

It has been suggested that four important factors are involved in bone formation: (1) cells directly involved in bone formation, (2) matrices produced by the cells, (3) mineral ions from body fluids, and (4) regulators of general cellular activities, including the calcification process ${ }^{1}$. Detailed analysis of these factors is the only way to fully understand this complex biological process.

We have recently tried to establish a stable source of the first factor, osteogenic cells, and combine them with the second factor, the matrix, to construct bone in vitro. In combining these two factors, we succeeded in constructing a bone-like structure in vitro by culturing bone marrow cells on collagen-gel ${ }^{2}$, without adding dexamethasone, a strong artificial differentiation-inducer which had previously been considered essential for the formation of a bone-like structure in this culture system ${ }^{3}$. This finding encouraged us to add the fourth factor, i. e., a cell regulator, to stromal cells in a collagen-gel system. The most feasible candidate regulator for this system was bone morphogenetic protein (BMP), a strong local factor which has not yet been detected in calf serum at a significant concentration. Regarding the third factor, mineral ions are usually well-supplied in culture medium and were not considered in this study.

BMP is a multi-functional cytokine and a member of the TGF- $\beta$ super gene family, which is ubiquitously distributed from Drosophila to mammals ${ }^{4-6,20)}$. BMPs were originally identified as growth and differentiation factors that stimulate immature mesenchymal cells to create a process similar to endochondral ossification when they are ectopically implanted with insoluble bone matrix as a carrier ${ }^{7,88}$. This unique feature of BMP has attracted the attention of clinicians in the fields of dentistry and orthopedics.
However, one of the problems which must be overcome before the clinical application of BMP is that this protein needs a proper carrier to function. A conventional bone insoluble matrix is not suitable for clinical use because of its putative impurity. Our research has shown that the BMP-inducible phenotype is highly dependent on the carrier when it is implanted into animal tissues ${ }^{9 \sim 12}$. The BMP carrier is now regarded as not only a drug-delivery system but also as an important matrix for cell attachment on which cells can undergo growth and differentiation in vivo ${ }^{13)}$.

These results strongly suggested that the addition of matrix-associated BMP to the culture may stimulate cells differently than the conventional addition of BMP to culture medium. In this regard, most of the previous studies on the effects of BMP in vitro have been performed in a matrix-free system ${ }^{14 \sim 19}$.

To our knowledge, there is no previous report concerning the effect of matrix-associated BMP on cell culture, despite the importance of this problem.

In this paper, we clearly demonstrate that the addition of collagen-combined BMP induces differentiation of bone marrow stromal cells into osteoblasts more effectively than the addition of BMP into medium.

\section{Materials and methods}

\section{Isolation of bone marrow stromal cells}

Bone marrow was obtained aseptically from the femora of 42-to 56-day-old male Wistar rats. The cleaned femora were washed 4 times (10 minutes each) with a culture medium containing a concentration of antibiotics 10 times higher than what is usually used. The marrow cells were flushed out by the usual culture medium and cultured in a $25 \mathrm{~cm}^{2}$ plastic culture flask (Falcon Labware, Oxnard, CA) containing $5 \mathrm{~m} l$ of culture medium. Primary cultured cells were maintained with a standard culture medium (see below).

A standard culture medium consisting of $\alpha$-modification of Eagle's minimum essential medium ( $\alpha$ MEM, Irvine Sci., Santa Ana, CA) was used. It contained $15 \%$ fetal calf serum (GIBCO, Grand island, 
NY) and antibiotics (100 units $/ \mathrm{m} l$ of penicillin $G$ [Meiji Seika, Tokyo, Japan] and $60 \mu \mathrm{g} / \mathrm{ml}$ of Kanamycin sulfate [Meiji Seika]).

When primary culture cells reached the confluent stage (approximately 4 days), bone marrow stromal cells were subcultured using a conventional technique employing $0.012 \%$ Pronase $^{\circledR}$ (Kaken Kagaku, Tokyo, Japan) and 2\% EDTA.

Cells were seeded in $35 \mathrm{~mm}$ plastic dishes (Falcon) at a plating density of $5 \sim 6 \times 10^{3}$ cells $/ \mathrm{cm}^{2}$ under the three different conditions described below, each with and without rBMP2.

2. Culture of bone marrow stromal cells with recombinant human BMP 2

Recombinant human BMP 2 (rBMP 2, a kind gift from Yamanouchi Seiyaku, Tokyo, Japan) was added to the cultured marrow stromal cells under three different conditions: (1) rBMP 2 was added to the standard medium, (2) rBMP 2 was added to the standard medium containing $10^{-8} \mathrm{M}$ dexamethasone (Dex) and $10 \mathrm{mM}$ sodium $\beta$-glycerophosphate $(\beta$ GP), and (3) rBMP 2 was added to collagen-gel on which the cells were cultured in the standard medium containing $3 \mathrm{mM} \boldsymbol{\beta}$-GP.

Condition 1 , culture in standard medium

Bone marrow stromal cells that reached confluence in the primary culture were inoculated on plastic dishes in the standard medium ( $2 \mathrm{ml} / \mathrm{dish}$ ) containing rBMP 2 at concentrations of 0,22 and $220 \mathrm{ng} / \mathrm{ml}$ medium, which was changed twice a week.

Condition 2, culture in Dex and $\beta$-GP

The cells were cultured in the standard medium (2 $\mathrm{m} l /$ dish) supplemented with $10^{-8} \mathrm{M}$ Dex, $10 \mathrm{mM} \beta^{-}$ $\mathrm{GP}$, and rBMP 2 at concentrations of 0,22 and $220 \mathrm{ng} /$ $\mathrm{m} l$. The medium changed twice a week.

\section{Condition 3, collagen-gel culture}

Type I collagen-gel was prepared as previously described $^{2}$,except that rBMP 2 was mixed in acidic collagen solution at different concentrations. The cells prepared as described above were inoculated on 35 mm plastic dishes that were sheeted with $1 \mathrm{ml} /$ dish of type I collagen-gel. The final concentration of collagen in the gel was $0.21 \%$. Concentrations of rBMP 2 in the gel were $0,44,440$ and $880 \mathrm{ng} / \mathrm{ml}$. Cultures were maintained in standard medium which contained 3 $\mathrm{mM} \beta-\mathrm{GP}$ and was changed twice a week.

\section{Biochemical analysis}

\section{Alkaline phosphatase activity}

Cell-matrix layers were harvested and washed three times with PBS. They were then homogenized in PBS, which contained $0.2 \%$ Nonidet P-40, $1 \mathrm{mM}$ $\mathrm{MgCl}_{2}$. Alkaline phosphatase activity (ALP) was measured by the Kind-King method ${ }^{21)}$.

\section{DNA content}

DNA contents were measured in these homogenized samples by fluorometric assay using a Hitachi F-3000 fluorescence spectrophotometer ${ }^{22)}$.

\section{Calcium content}

Calcium content was measured by the Ortho-Cresolphthalein Complexon (OCPC) method ${ }^{23}$.

\section{Osteocalcin content}

To measure osteocalcin released into the medium, we used serum-free conditioned medium in which cells were maintained for $12 \mathrm{~h}$. Osteocalcin content was determined by radioimmunoassay (RIA) ${ }^{24}$. Rat osteocalcin (Biomedical Technologies Inc., U.S. A.) was used as a standard. Goat anti-rat osteocalcin (Biomedical Technologies inc.) was used as a second antibody. Rat osteocalcin was labeled with ${ }^{125} \mathrm{I}$ by the lactoperoxidase method.

\section{Results}

\section{Morphological changes (Fig. 1)}

Bone marrow cells from rat femora which were primarily cultured on plastic dishes showed a fibroblast-like shape and attained confluence at 4 days after inoculation. These cells were subcultured at a plating density of $5 \sim 6 \times 10^{3} \mathrm{cells} / \mathrm{cm}^{2}$. On conventional plastic dishes (condition 1) without BMP, they showed a fibroblast-like shape and attained confluence from 4 to 5 days after inoculation. However, these cells remained fibroblast-like after confluence and had created neither cellular aggregation nor nodules, as shown in Fig. 1B, at Day 7 after inoculation. With the addition of rBMP 2 at concentrations of 22 and $220 \mathrm{ng}$ per $\mathrm{m} l$ of medium, no morphological differences from the experiments without rBMP 2 could be observed by 

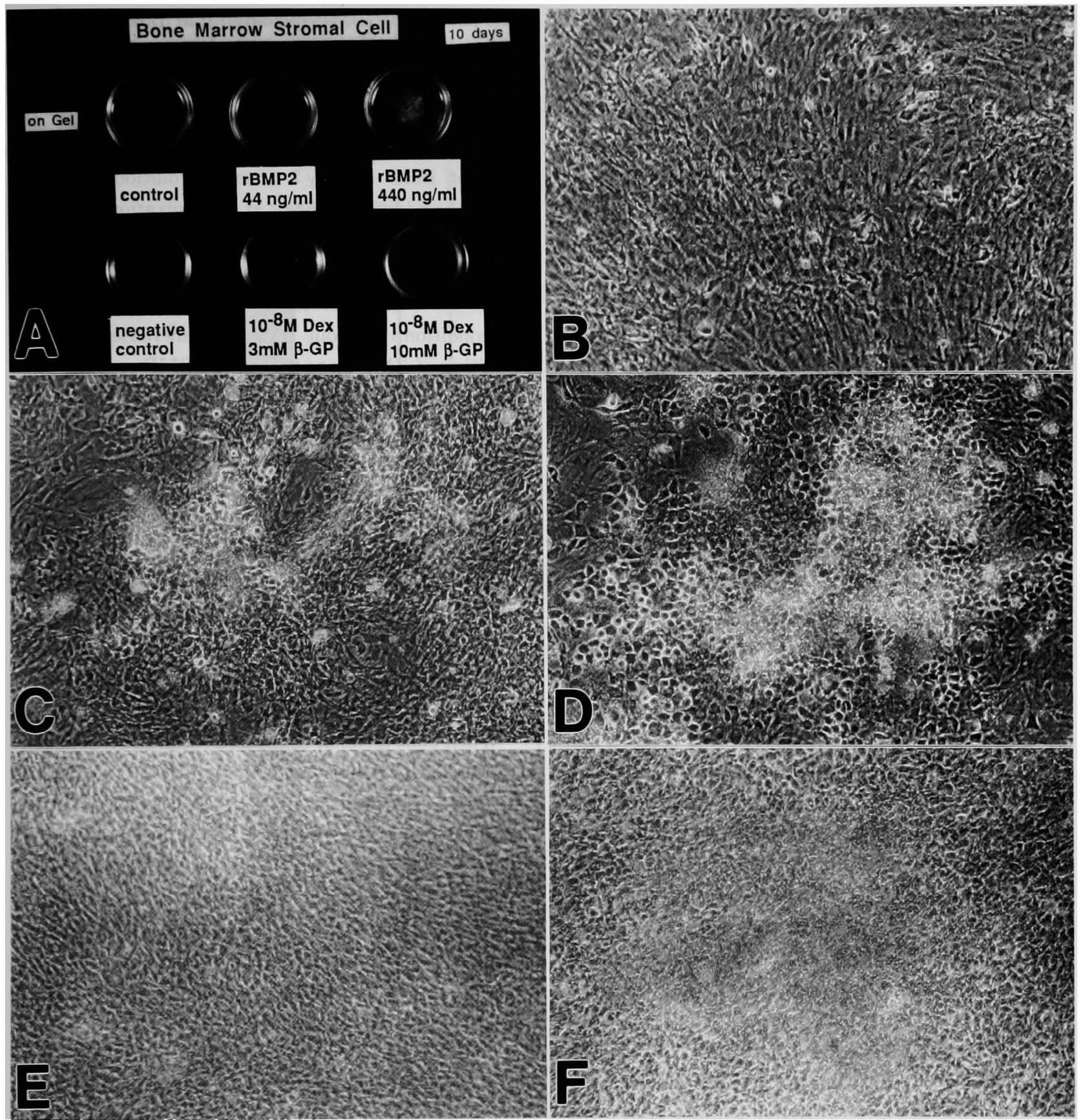

Fig. 1 Histological changes of bone marrow cells induced by rBMP 2.(A): Photograph of culture dishes (35 mm diameter). Cells were cultured on type I collagen gel (top row) and conventional culture dish (bottom row). White spots were calcified nodules. Phase-contrast micrographs $(B \sim F)$ of bone marrow stromal cells (original magnification $\times 100$ ). Cells were plated at $5 \sim 6 \times 10^{3}$ cells $/ \mathrm{cm}^{2}$ and cultured on conventional culture dish (B, C, D) and on type I collagen gel (E, F) for 7 days. (B) : St. Mem. (C) : $10^{-8} \mathrm{M}$ dexamethasone (Dex), $10 \mathrm{mM} \beta-$ glycerophosphate $(\beta-\mathrm{GP})$ (D) : Dex, $\beta-\mathrm{GP}, \mathrm{rBMP} 2,220 \mathrm{ng} / \mathrm{m} l$ (E) : on gel culture (F) : on gel culture supplmented with $\mathrm{rBMP} 2,440 \mathrm{ng} / \mathrm{ml}$ 
phase-contrast microscopy.

Under condition 2, cells cultured without rBMP 2 attained a confluent state at $4 \sim 5$ days after inoculation. After confluence, these cells assumed polygonal shapes, and began to form small nodules scattered throughout the dish. At Day 7 after inoculation, these nodules had grown and showed an opaque area in their central regions, which is characteristic of calcified nodules $^{3,34)}$ (Fig. 1C). With rBMP 2 at a concentration of $220 \mathrm{ng}$ per $\mathrm{m} l$ of medium, definite calcified nodules appeared earlier than without rBMP 2. In addition, the opaque areas in their central regions were much larger than those observed without rBMP 2 (Fig. 1D).

Under condition 3, cells inoculated on collagen-gel without rBMP 2 attained confluence at $4 \sim 5$ days, assumed a polygonal shape, and continued to grow , similar to those in condition 2. A large number of the characteristic calcified nodules appeared at Day 14 after inoculation, which was about one week after that in condition 2 without rBMP 2 .

Bone marrow stromal cells cultured on collagen-gel containing rBMP 2 (440 ng per gel) produced a large number of calcified nodules much earlier than those cultured on collagen-gel without rBMP 2 (Fig. 1E and F). Calcified nodule formation under this condition occurred at almost the same time as under condition 2 with and without BMP. These calcified nodules were observed as white plaques on a dark background (Fig. 1A). The calcified area in each nodule became larger and the nodules fused together to form larger nodules when the concentration of rBMP 2 increased as shown in the upper portion of Figure 1A.

\section{Biochemical changes (Figs. 2 6)}

Under condition 1, alkaline phosphatase activity was quite low ( $5.9 \mathrm{mIU} / \mu \mathrm{gDNA}$ ) without BMP, and this value increased only slightly with $B M P$, even at a concentration of $220 \mathrm{ng} / \mathrm{m} l$ (Fig. 2A). The DNA content increased about 3 -fold with the addition of BMP at the same concentration (Fig. 2B). However, the calcium content did not show any increase, and in fact showed a tendency to slightly decrease, with the addition of BMP, which is consistent with the observation that there were no calcified nodules in the culture (Fig. 1B). These changes in biochemical markers with the addition of BMP indicated that BMP had only a minimum effect on the cells under these conditions.

Under condition 2, in which Dex and $\beta$-GP were present in the medium, ALP activity was 10 -fold higher than that in condition 1 even without the addition of BMP at Day 7 after inoculation (Fig. 3A). With the addition of BMP at concentrations of 22 and $220 \mathrm{ng} / \mathrm{m} l$, ALP activity showed a considerable increase, (1.2-and 1.3-fold, respectively) (Fig. 3A). In addition, calcium content was 3 times higher than that in condition 1 without BMP, and increased with the addition of BMP up to 2-fold at a BMP concentration of $220 \mathrm{ng} / \mathrm{ml}$ of medium (Fig. 3C). The osteocalcin content increased with the addition of BMP, while the DNA content did not change (Fig. 3B and D). Under condition 2 , bone marrow cells clearly produced calcified nodules even without the addition of BMP, as has been well documented. Thus, the addition of BMP to this system further increased ALP activity, calcium content and osteocalcin. These observations agreed with morphological findings that calcified nodules increased in size and number with the addition of BMP (Figs. 1C, D).

When bone stromal cells were cultured on collagengel (condition 3) for 7 days without BMP, ALP activity was higher than that in both conditions 1 and 2, (15and 1.6-fold, respectively) (Figs. $2 \mathrm{~A}, 3 \mathrm{~A}$ and $5 \mathrm{~A}$ ). Figure 4 shows that ALP activity and calcium content on the collagen-gel culture increased with the addition of BMP at Day 10 after inoculation. ALP activity increased in a dose-dependent manner for all of the concentrations examined, while calcium content leveled off at $880 \mathrm{ng} / \mathrm{m} l$ of gel.

\section{Time-dependent changes in the gel-culture}

Figure 5 shows the time-dependent changes in ALP activity, DNA, calcium and osteocalcin contents produced by the cells cultured on collagen-gel with and without the addition of BMP. ALP activity, calcium and osteocalcin contents each showed a characteristic time-dependent change. With the addition of rBMP 2, ALP activity was high at 1 week and declined at 2 and 3 weeks after inoculation. Similarly, osteocalcin content was high at 1 and 2 weeks and decreased at 3 weeks. In contrast, both markers 

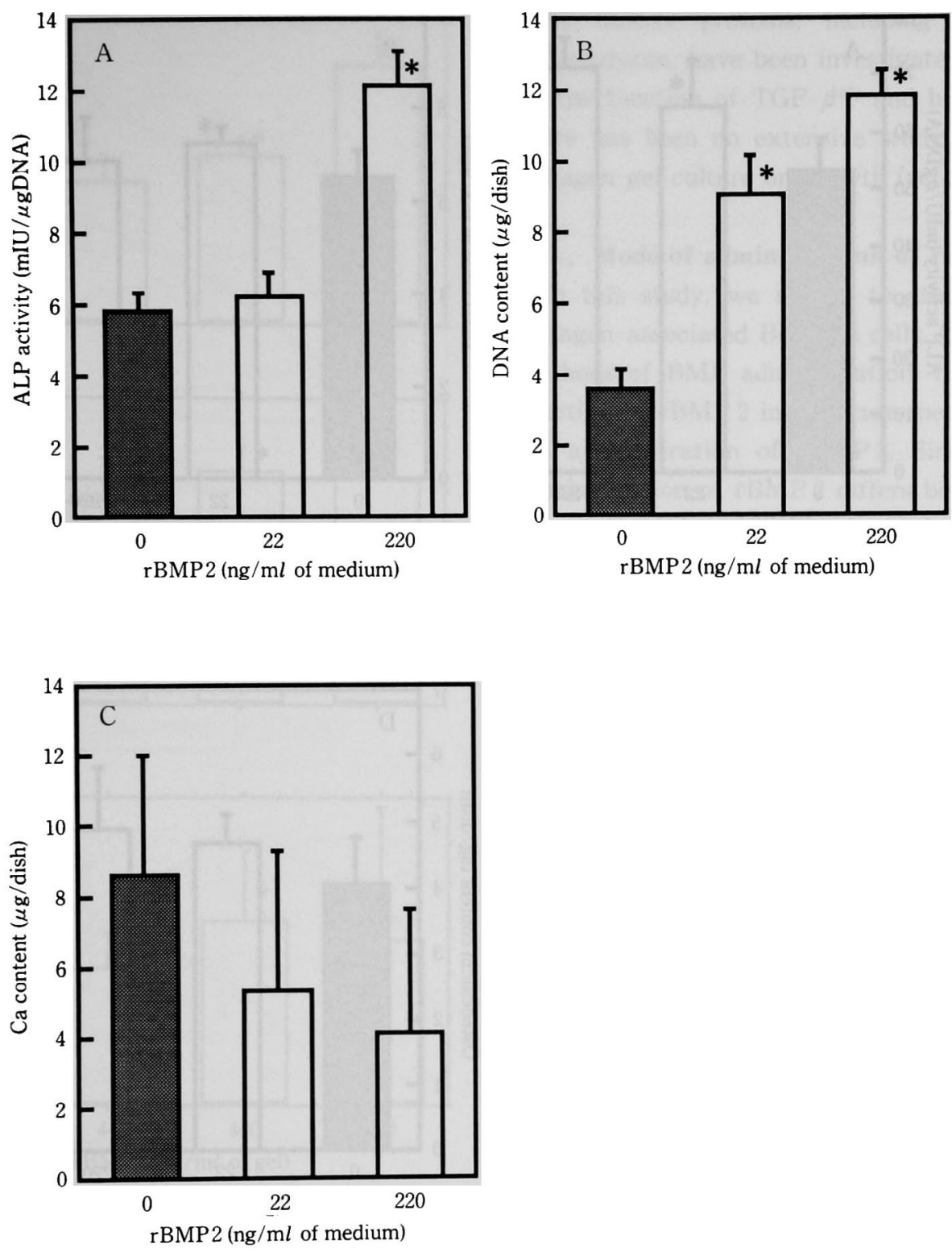

Fig. 2 The effect of rBMP2 on the activiiy of bone marrow cells. Different concentrations of rBMP2 were supplemented with standard medium. Cells were plated on $35 \mathrm{~mm}$-culture dish and cultured for 7 days with these medium.

(A) ALP activity, (B) DNA content, (C) Ca content

Results are expressed as the mean \pm S. D. $(n=4)$. Significantly different from the control without rBMP2 by Student $t$-test. $(* p<0.05)$

showed a clear time-dependent increase when the cells were cultured on collagen-gel without rBMP 2 (Figs. 5A, D). Contents of DNA and calcium increased almost linearly with time (Figs. 5B, C).

Further, the time-dependent change in ALP activity was investigated in an earlier stage of culture (Fig. 6). Without the addition of BMP, ALP activity showed a clear time-dependent increase from Day 3 after cell inoculation. In contrast, ALP activity with BMP (440 $\mathrm{ng} / \mathrm{m} l$ ) was about 1.7 -fold higher than that without 

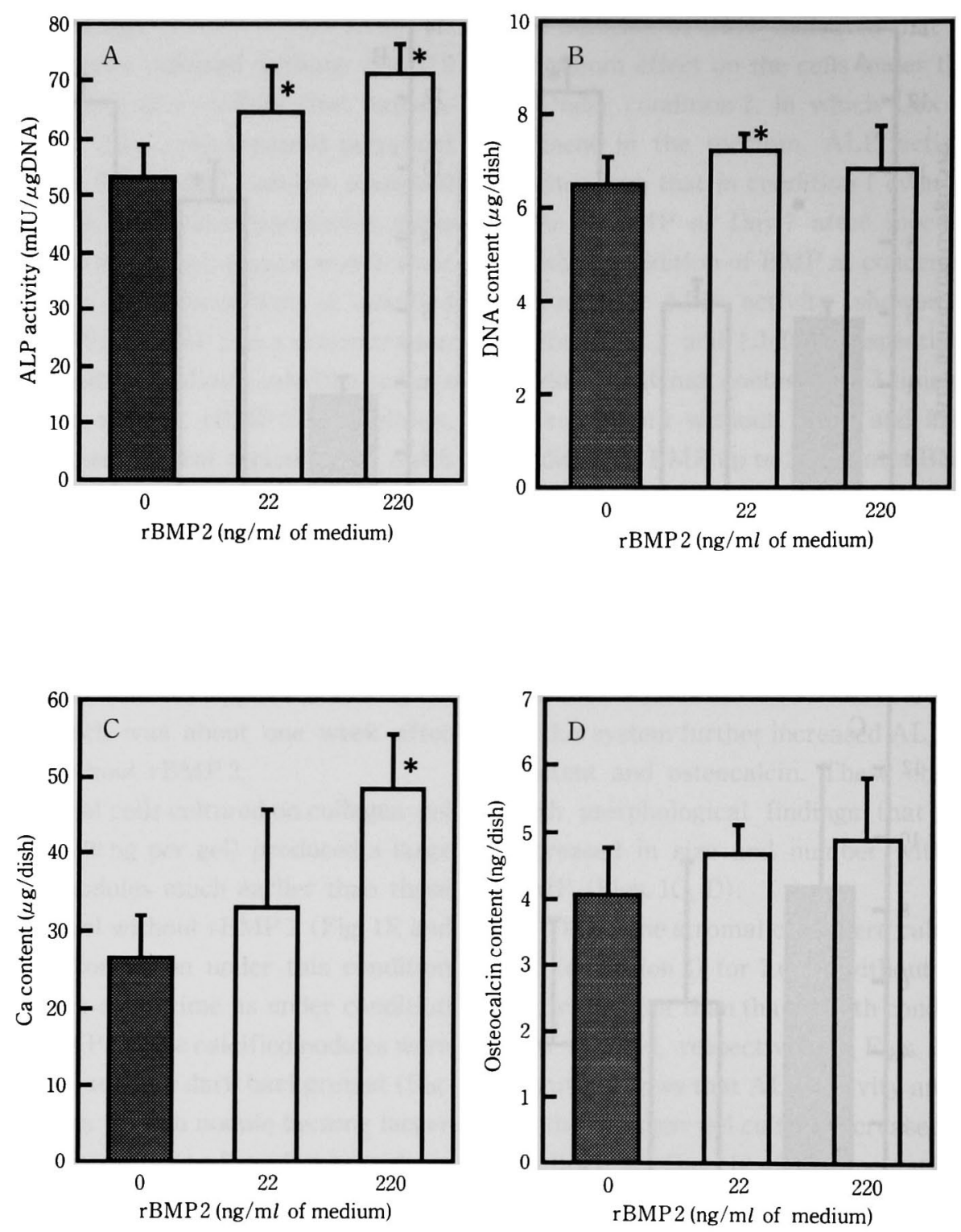

Fig. 3 The effect of rBMP2 on the activity of bone marrow cells. Different concentrations of $\mathrm{rBMP} 2$ were supplemented with standard medium containing $10^{-8} \mathrm{M}$ Dexamethasone (Dex), and $10 \mathrm{mM} \beta$-glycerophosphate $(\beta$-GP). Cells were plated on $35 \mathrm{~mm}$-culture dish and cultured for 7 days with these medium.

(A) ALP activity, (B) DNA content, (C) Ca content, (D) Osteocalcin content Results are expressed as the mean \pm S. D. $(n=4 \sim 8)$. Significantly different from the control without rBMP2 by Student $\mathrm{t}$-test. $\left({ }^{*} \mathrm{p}<0.05\right)$

BMP at Day 3 and attained a peak at Day 7. The activity decreased thereafter.

\section{Discussion}

In this study, we demonstrated for the first time that collagen-gel, as a cell substratum, modulated the 

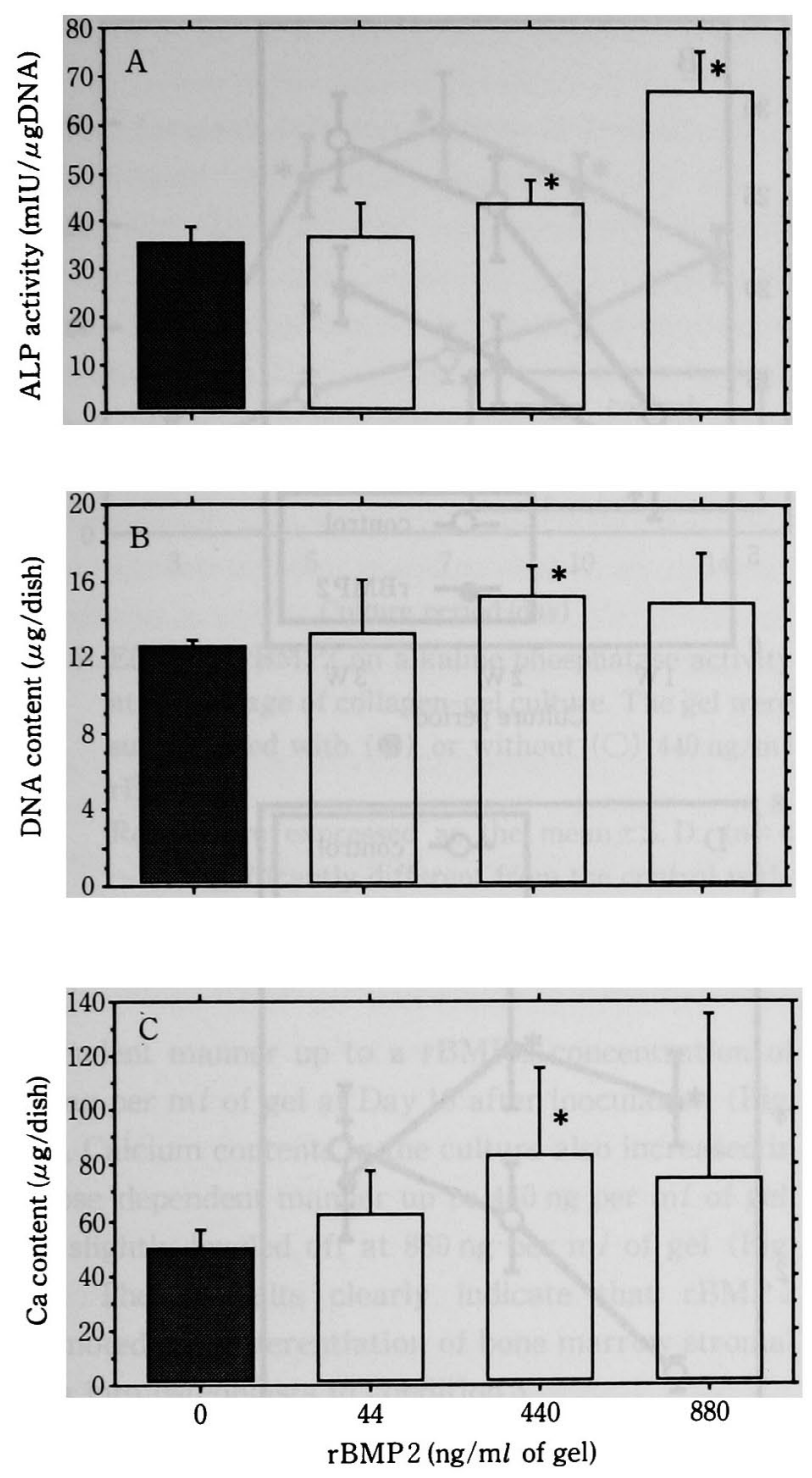

Fig. 4 The effect of several concentrations of rBMP2 on the expression of osteoblastic phenotypes of bone marrow cells cultured on type I collagen gel for 10 days.
(A) ALP activity, (B) DNA content, (C) Ca con- tent

Results are expressed as the mean \pm S. D. $(n=4)$. Significantly different from the control without rBMP2 by Student $\mathrm{t}$-test. $\left({ }^{*} \mathrm{p}<0.05\right)$

effect of BMP on cultured marrow cells in their differentiation into osteoblasts. Recently, the matrixmediated function of various growth factors has attracted the attention of researchers in cell biology and clinical fields. Several noncollagenous extracel- lular matrix proteins, including heparan sulfate proteoglycan, have been investigated for their effect on the function of $\mathrm{TGF}-\boldsymbol{\beta}^{25)}$ and $\mathrm{bFGF}^{26)}$. However, there has been no extensive study of the effect of collagen-gel culture on growth factor functions.

\section{Mode of administration of $\mathbf{r B M P} 2$}

In this study, we sought to study the effect of collagen-associated BMP on cells. We compared the methods of BMP administration, i. e., conventional addition of rBMP 2 into culture medium and the ingel administration of rBMP2. Since the mode of administration of rBMP 2 differs between the in-gel system and the conventional addition to the medium, it is difficult to compare the effects strictly by the concentration of rBMP 2 . Therefore, we added equivalent contents per dish as a matter of convenience. Since $2 \mathrm{~m} l$ of the BMP-free medium and $1 \mathrm{~m} l$ of the gel which contained BMP were added per dish under condition 3, the total of $440 \mathrm{ng}$ of BMP per dish in condition 3 , for example, was equivalent to the $220 \mathrm{ng}$ in condition 2.

\section{Ineffectiveness of conventional administra- tion (condition 1)}

Figures $1 \mathrm{~B}$ and 2 indicate that under condition 1 without the addition of rBMP 2, biochemical markers of osteoblastic phenotype such as ALP activity and calcium content were minimum, compared with those in condition 2, which was supplemented with Dex and $\beta$-GP for 7 days after inoculation. The addition of $\mathrm{rBMP} 2(220 \mathrm{ng} / \mathrm{ml}: 440 \mathrm{ng} / \mathrm{dish})$ to this system increased ALP activity to $12 \mathrm{mIU} / \mu \mathrm{gDNA}$, which was much lower than that in condition 2. The apparent decrease in calcium content (Fig. $2 \mathrm{C}$ ) was considered to be neglible. Although the DNA content significantly increased in a dose-dependent manner (Fig. 2B), the cells did not show any sign of calcified nodule formation even after a prolonged culture, with or without rBMP 2 under this condition.

With the addition of rBMP 2 in condition 2, in which the medium contained Dex and $\beta$-GP, the cells produced higher ALP activity, calcium and osteocalcin contents than the control without rBMP 2, but DNA content did not change significantly, indicating 

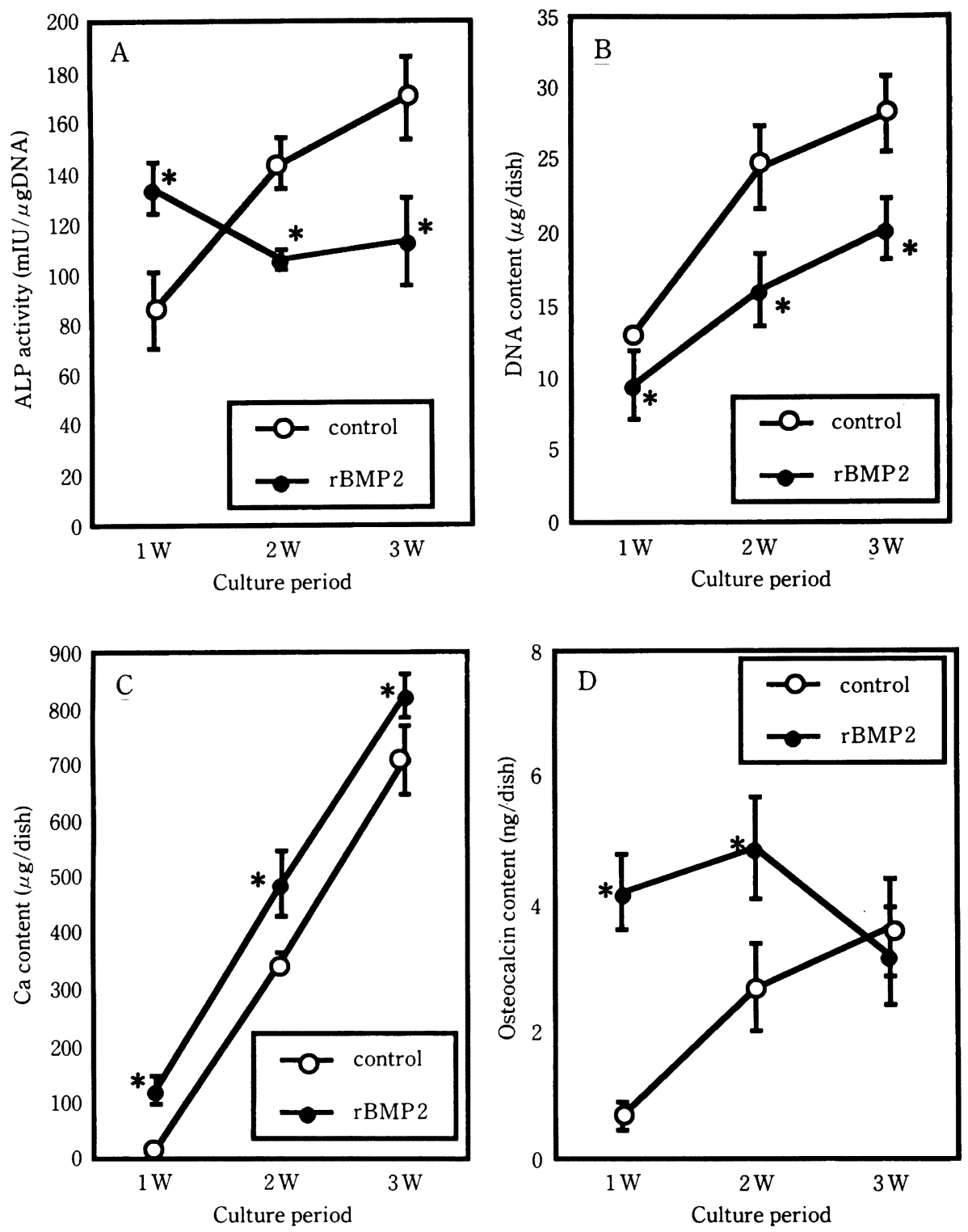

Fig. 5 Effect of rBMP2 on alkaline phosphatase activity, DNA content, Ca content and osteocalcin content when rat bone marrow stromal cells were cultured on type I collagen gel. Cells were plated with the density of $5 \sim 6 \times 10^{3} \mathrm{cells} / \mathrm{cm}^{2}$ in $35 \mathrm{~mm}$ culture dishes and grown for 3 weeks on gel supplmented with (O) or without $(\bigcirc) 440 \mathrm{ng} / \mathrm{m} l \mathrm{rBMP} 2$. After 1,2 , and 3weeks in culture, cells were harvested and assayed for ALP activity (A), DNA content (B), Ca content (C) and osteocalcin content (D).

Results are expressed as the mean \pm S. D. $(n=4)$. Significantly different from the control without rBMP2 by Student $\mathrm{t}$-test. $\left({ }^{*} \mathrm{p}<0.05\right)$

that rBMP 2 definitely promoted the cells to differentiate into osteoblasts in condition 2.

\section{Effectiveness of In-Gel Administration (con- dition 3)}

With the addition of rBMP 2 to collagen-gel, bone marrow cells showed a higher ALP activity in a dose- 


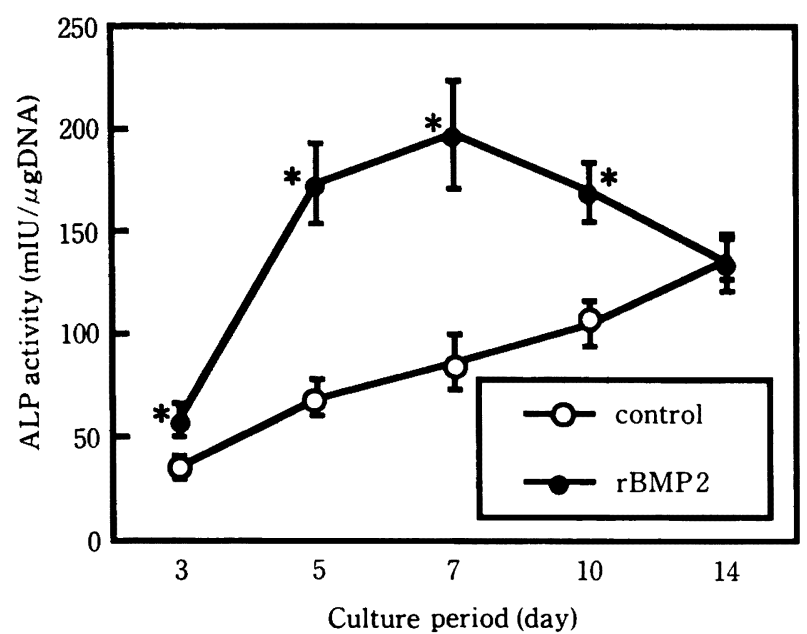

Fig. 6 Effect of rBMP2 on alkaline phosphatase activity at early stage of collagen-gel culture. The gel were supplmented with $(O)$ or without $(\bigcirc) 440 \mathrm{ng} / \mathrm{ml}$ rBMP2.

Results are expressed as the mean \pm S. D. ( $n=4$ $\sim 6$ ). Significantly different from the control without rBMP2 by Student t-test. ( $\left.{ }^{*} \mathrm{p}<0.05\right)$

dependent manner up to a rBMP 2 concentration of $880 \mathrm{ng}$ per $\mathrm{m} l$ of gel at Day 10 after inoculation (Fig. $4 \mathrm{~A})$. Calcium contents in the culture also increased in a dose-dependent manner up to $440 \mathrm{ng}$ per $\mathrm{m} l$ of gel, but slightly leveled off at $880 \mathrm{ng}$ per $\mathrm{m} l$ of gel (Fig. $4 \mathrm{C})$. These results clearly indicate that rBMP 2 promoted the differentiation of bone marrow stromal cells into osteoblasts in condition 3.

\section{Acceleration of differentiation by BMP}

Figures 5 and 6 show the time-dependent changes in ALP activity and DNA, calcium and osteocalcin contents produced by bone marrow cells cultured on collagen-gel and rBMP $2(440 \mathrm{ng} / \mathrm{m} l$ of gel). The time-dependent increases in all four markers without rBMP 2 indicate that collagen-gel itself is a good cell substratum for bone marrow cells to differentiate into osteoblasts, as previously reported ${ }^{2}$. Since bone marrow stromal cells are heterogeneous cell populations, we could not consider these cells as identical even though they were derived from rats of the same strain. However, it should be emphasized that with addition of rBMP 2, ALP activity was highest at Day 7 after inoculation and decreased thereafter, as shown in
Figures $5 \mathrm{~A}$ and 6. Likewise, osteocalcin content reached a peak at 2 weeks. These results clearly indicate that rBMP 2 accelerated differentiation in this system.

\section{Evidence of bone-like mineralization}

It should be emphasized that the most remarkable effect of rBMP 2 on bone marrow stromal cells in condition 3 was the increased production of osteocalcin and ALP at Day 7 (Fig. 5A and D). Figure 6, also shows that ALP activity reached a maximum level at one week. Without rBMP 2, osteocalcin was produced in only a trace amount at 1 week. Osteocalcin is known to be the most important marker for the later stage of bone formation ${ }^{27-29)}$. Sampath et al. ${ }^{30)}$ reported that OP-1 (BMP 7) induced the production of osteocalcin by osteoblast-like cells derived from rat calvaria at Day 7 after inoculation, and that this production of osteocalcin reached a maximum at 2 weeks and leveled off thereafter.

This finding is consistent with our present observation that the production of osteocalcin leveled off after 2 weeks in condition 3 with rBMP 2 (Fig. 5D).

The content of calcium in the cell-matrix layer of the culture with rBMP 2 increased linearly from 1 to 3 weeks after inoculation. These values were higher than those without rBMP 2 in the collagen-gel system, which is indicative of a higher degree of calcification. In comparison with Figure $3 \mathrm{C}$, it is surprising that the calcium content ( $120 \mu \mathrm{g}$ per dish) in condition 3 with rBMP 2 was much higher than that ( $48 \mu$ g per dish) in condition 2 with rBMP 2 at one week. We previously confirmed that mineralization occurred in the matrix vesicle and collagen fibrils in the calcified nodules, and that the deposited minerals were hydroxyapatitelike in nature ${ }^{2)}$. However, we can not exclude the possibility that collagen-gel itself was also calcified to an extent which can not be recognized by morphological observation, and that a small fraction of the calcium content was deposited in the collagen-gel rather than in calcified nodules.

Since bone marrow stromal cells are heterogeneous cell populations, we could not consider these cells as identical even though they were derived from rats of the same strain. This situation resulted in the some- 
what different values among Figures 4, 5 and 6 . For example, in Figure 4, ALP activities of the control and BMP groups ( $440 \mathrm{ng} / \mathrm{m} l$ of gel) were 36 and $44 \mathrm{mIU} /$ $\mu \mathrm{gDNA}$, respectively, at Day 10. On the other hand, in Figure 6, those of the control and BMP groups were 105 and $169 \mathrm{mIU} / \mu \mathrm{gDNA}$, respectively at Day 10 . These differences among the cell sources were considered unavoidable with the present technique and should be improved in future studies.

\section{Comparison with previous reports}

There have been numerous examples of BMPs affecting the differentiation of osteogenic cells and related cells in culture. Katagiri et al. ${ }^{19)}$ reported that with the addition of BMP, the non-osteogenic mouse pluripotent cell line $\mathrm{C} 3 \mathrm{H} 10 \mathrm{~T} 1 / 2$ could be induced to differentiate into osteogenic cells, based on the increase in ALP activity and the cAMP response to $\mathrm{PTH}^{19}$. Yamaguchi et $a l .{ }^{31)}$ reported the effect of BMP 2 on two clonal cell lines of rat osteoblast-like cells at different differentiation stages ; ROB-C20 and C26. Only the uncommitted cell line (C26) could be induced by rBMP 2 to produce a high ALP activity in a conventional $\alpha$-MEM medium ${ }^{31}$. The osteogenic cell line $\mathrm{MC} 3 \mathrm{~T} 3-\mathrm{E1}^{32 \sim 34)}$ has also been studied by several groups of researchers with regard to the effect of BMP ${ }^{14,16,17)}$. They all showed an increase in ALP activity with the addition of BMP, which is consistent with our present results. Rickard et al. ${ }^{38)}$ reported that Dex and BMP-2 could induce the rapid differentiation of osteoblastic cells from uncommitted stromal cells resident in rat bone marrow. This result is consistent with our present results. However, in their study, ALP activity in the Dex-treated culture was as high as that in the BMP-treated culture, while in our study, ALP activity with Dex was 4.4 times higher than that with BMP $(220 \mathrm{ng} / \mathrm{m} l)$. This discrepancy may be due to the types of cells used : Rickard $e t a l^{38)}$ used primary cells from the whole marrow of femurs of 4-to 5-week -old-female Wistar rats, and we used secondary cells from the femora of 42-to 56-day-old male Wistar rats. As far as we know, no report has clearly shown the effect of matrix on BMP function in vitro, and our study is the first to demonstrate a strong positive effect of collagen-gel on BMP function to induce cell differentiation.

\section{Biological significance of the present findings}

The present results suggest that bone marrow stromal cells are target cells for BMP function and that the resulting induction is directed toward differentiation into osteoblasts. It has been shown that bone marrow cells are a heterogeneous population which can differentiate into osteoblast-like cell ${ }^{2,3)}$, chondrocyte $^{34)}$ or adipocyte ${ }^{35)}$, depending upon the conditions applied to the culture. Our studies showed that culture of these cells on collagen-gel may facilitate them to differentiate into osteoblasts, and the ingel addition of BMP further enhances this differentiation.

In the in vivo study of BMP-induced bone formation, it has been demonstrated that BMP requires a carrier for its function. In an attempt to clarify the role of this carrier, extensive studies on the effects of various carriers have been performed ${ }^{8-12)}$. Kuboki et al. ${ }^{13)}$ recently concluded that the BMP carrier is not only a drug-delivery system, but also an important cell substratum on which cells can undergo growth and differentiation. This conclusion may apply to the addition of BMP to cells on collagen-gel culture reported here. Rickard et al. ${ }^{38)}$ reported that Dex and BMP-2 separately induced a variety of differentiated osteoblast markers when both agents were added together. They suggested that Dex might act on more primitive cells than BMP-2 since successive exposure of stromal cells to Dex followed by BMP-2 was more effective at inducing high ALP activity than administering these inducers in the reverse order. Similarly, the enhanced effect of rBMP 2 by combination with collagen-gel may be interpreted in several ways. First, collagen-gel may help to condense the cells and activate cellular activity via collagen receptors. These activated cells are surrounded by growth factors in the matrix, and the continuous stimulation by these growth factors may eventually promote differentiation into osteoblasts. Recent studies on collagen-gel associated with growth factor have revealed that the adhesion of cells to the gel resulted in a sequence of events which begins with collagen interaction. One of the remarkable events in this sequence is the reorgani- 
zation of actin fiber, which may activate cells for differentiation. In this regard, the effect of BMP in gel may fundamentally differ from that in conventional plastic dishes.

Recently, Asahina et al. ${ }^{37)}$ demonstrated that the addition of OP-1 to rat calvaria-derived cells at an early stage induced them to differentiate into chondrogenic cells, while the addition of BMP at a later stage after confluence induced them to differentiate into osteogenic cells. Their results encourage us to investigate the possibility that bone marrow stromal cells can also differentiate into either osteogenic or chondrogenic cells depending on the collagen-gel culture conditions.

\section{Acknowledgments}

This study was supported in part by Grants-in-Aid (Nos. 02454421, 03364041 and 03305001) from the Ministry of Science, Education and Culture of Japan.

\section{References}

1) Kuboki, Y., Yamaguchi, H., Yokoyama, A., Murata, M., Takita, H., Tazaki, M., Mizuno, M., Hasegawa, T., Iida, S., Shigenobu, K., Fujisawa, R., Kawamura, M., Atuta, T., Matumoto, A., Kato, H., Zhou, H-Y., Ono, I., Takeshita, N. and Nagai, N. : Osteogenesis induced by BMP-coated biomaterials : Biochemical principles of bone reconstruction in dentistry. (ed. by Davis J. D.) pp 127 138, Univ. Toronto Press, Toronto, 1991.

2) Hasegawa, T., Oguchi, H., Mizuno, M. and Kubo$\mathrm{ki}, \mathrm{Y}$ : The effect of the extracellular matrix on the differentiation of bone marrow stromal cells to osteoblasts. Jpn. J. Oral Biol. $36: 383 \sim 394$, 1994.

3) Maniatopoulos, C., Sodeck, J. and Melcher, A. $\mathrm{H}$. : Bone formation in vitro by stromal cells obtained from bone marrow of young adult rats. Cell Tissue Res. $254:$ 317 330, 1988.

4) Wang, E. A., Rosen, V., Cordes, P., Hewick, R. M., Kriz, M. J., Luxenberg, D. P., Sibley, B.S. and Wozney, J. M. : Purification and characterization of other distinct bone-inducing factors. Proc. Natl. Acad. Sci. USA 85 : 9484 9488, 1988.

5) Wozney, J. M., Rosen, V., Celeste, A. J., Mitsock,
L. M., Whitters, M. J., Kriz, R. W., Hewick, R. M. and Wang, E. A. : Novel regulators of bone formation: Molecular clones and activities. Science 242: 1528 1534, 1988.

6) Celeste, A. J., Iannazzi, J. A., Taylor, R. C., Hewick, R. M., Rosen, V., Wang, E. A. and Wozney, J. M. : Identification of transforming growth factor $\beta$ family members present in bone-inductive protein purified from bovine bone. Proc. Natl. Acad. Sci. USA 87 : 9843 9847, 1990.

7) Urist, M. R. : Bone : formation by autoinduction. Science $150:$ : 893 899, 1965.

8) Sampath, T. K. and Reddi, A. H. : Importance of geometry of the extracellular matrix in endochondral bone differentiation. J. Cell Biol. 98: 2192 $\sim 2197,1984$.

9) Ono, I., Ohura, T., Murata, M., Yamaguchi, H., Ohnuma, Y. and Kuboki, Y. : A study on bone induction in hydroxyapatite combined with bone morphogenetic protein. Plast. Reconstr. Surg. $90: 870 \sim 879,1992$.

10) Sasano, Y., Ohtani, E, Narita, K., Kagayama, M., Murata, M., Saito, T., Shigenobu, K., Takita, H., Mizuno, M. and Kuboki, Y. : BMPs induce direct bone formation in ectopic sites independent of the endochondral ossification in vivo. Anat. Rec. 236 : 373-380, 1993.

11) Shigenobu, K., Kaneda, K., Nagai, N. and Kuboki, Y. : Localization of bone morphogenetic proteininduced bone and cartilage formation on a new carrier: fibrous collagen membrane. Ann. Chir. Gynaecol. 82 : 85 90, 1993.

12) Missana, L., Nagai, N. and Kuboki, Y. : Comparative histological studies of bone and cartilage formations induced by various BMP-carrier composites. Jpn. J. Oral Biol. 36 : 9 19, 1994.

13) Kuboki, Y., Saito, T., Murata, M., Takita, H., Mizuno, M., Inoue, M., Nagai, N. and Poole, A. R. : Two distinctive BMP-carriers induce Zonal chondrogenesis and membranous ossification, respectively : geometrical factors of metrices for cell-differentiation. Conn. Tiss, Res. in press.

14) Vukicevic, S., Luyten, F. P. and Reddi, A. H. : Osteogenin inhibits proliferation and stimulates differentiation in mouse osteoblast-like cells (MC3T3-E1). Biochem. Biophys. Res. Commun. $166: 750 \sim 756,1990$.

15) Vukicevic, S., Luyten, F. P. and Reddi, A. H. : Stimulation of the expression of osteogenic and 
chondrogenic phenotypes in vitro by osteogenin. Proc. Natl. Acad. Sci. USA. 86 : 8793 8797, 1989.

16) Hiraki, Y., Inoue, H., Shigeno, C., Sanma, Y., Bentz, H., Rosen, D. M., Asada, A. and Suzuki, $\mathrm{F}$. : Bone morphogenetic proteins (BMP-2 and BMP-3) promote growth and expression of the differentiated phenotype of rabbit chondrocytes and osteoblastic MC3T3-E1 cells in vitro. J. Bone Miner. Res. 61 : 1373 1385, 1991.

17) Takuwa, Y., Ohse, C., Wang, A., Wozney, J. M. and Yamashita, K. : Bone morphogenetic protein2 stimulates alkaline phosphatase activity and collagen synthesis in cultured osteoblastic cells, MC3T3-E1. Biochem. Biophys. Res. Commun. 174: 96〜 101, 1991.

18) Thies, R. S., Bauduy, M., Ashton, B. A., Kurtzberg, L., Wozney, J. M. and Rosen, V. : Recombinant human bone morphogenetic protein-2 induces osteoblastic differentiation in W-20-17 stromal cells. Endocrinology. 130: 1318 1324, 1992.

19) Katagiri, T., Yamaguchi, A., Ikeda, T., Yoshiki, S., Wozney, J. M., Rosen, V., Wang, E. A., Tanaka, H., Omura, S. and Suda, T.: The nonosteogenic mouse pluripotent cell line, C3H10T1/ 2 , is induced to differentiate into osteoblastic cells by recombinant human bone morphogenetic protein-2. Biochem. Biophys. Res. Commun. $172: 295$ 〜299, 1990.

20) Wang, E. A., Rosen, V., Baudy, V., Cordes, P., Harada, T., Israel, D. I., Hewick, R. M., Kerns, K. M., Lapan, P., Luxenberg, D. P., McQuaid, D., Moutsatsos, I. K., Nove, J. and Wozney, J. M. : Recombinant human bone morphogenetic protein induces bone formation. Proc. Natl. Acad. Sci. $87: 2220 \sim 2224,1990$.

21) Kind, P. R. N. and King, E. J. : Estimation of plasma phosphatase by determination of hydrolysed phenol with amino-antipyrine. J. Clin. Path. $7: 322 \sim 326,1954$.

22) Kissane, J. M. and Robins, E. : The fluorometric measurement of deoxyribonucleic acid in animal tissues with special reference to the central nervous system. J. Biol. Chem. $233: 184 \sim 188,1958$.

23) Connerty, H. V. and Briggs, A. R. : Determination of serum calcium by means of orthocresolphth alein complexone. Am. J. Clin. Path. 45:290 〜296, 1966.

24) Price, P. A. and Nishimoto, S. K. : Radioimmunoassay for the vitamin $\mathrm{K}$-dependent protein of bone and its discovery in plasma. Proc. Natl. Acad. Sci. $77: 2234 \sim 2238,1980$.

25) Madri, J. A., Pratt, B. M. and Tucker, A. M. : Phenotypic modulation of endothelial cells by transforming growth factor- $\beta$ depends upon the composition and organization of the extracellular matrix. J. Cell Biol. 106 : 1375 1384, 1988.

26) Vigny, M., Ollier-Hartmann, M. P., Lavigne, M., Fayein, N., Jeanny, J. C., Laurent, M. and Courtois, Y.: Specific binding of basic fibroblast growth factor to basement membrane-like structures and to purified heparan sulfate proteoglycan of the EHS tumor. J. Cell. Physiol. $137: 321 \sim 328$, 1988.

27) Bronckers, A. L. J. J., Gay, S., Finkelman, R. D. and Butler, W. T. : Developmental appearance of Gla proteins (osteocalcin) and alkaline phosphatase in tooth germ and bones of the rat. Bone Miner. $2: 361 \sim 373,1987$.

28) Lian, J. B. and Gundberg, C. M. : Osteocalcin : biochemical considerations and clinical applications. Clin. Orthop. 226:267 291, 1988.

29) Strauss, P. G., Closs, E. I., Schmidt, J. and Erfle, V. : Gene expression during osteogenic differentiation in mandibular condyles in vitro. J. Cell Biol. $110: 1369 \sim 1378,1990$.

30) Sampath, T. K., Maliakal, J. C., Hauschka, P. V., Jones, W. K., Sasak, H., Tucker, R. F., White, K. H., Coughlin, J. E., Tucker, M. M., Pang, R. H., Corbett, C., Özkaynak, E., Oppermann, H. and Rueger, D. C. : Recombinant human osteogenic protein (hOP-1) induces new bone formation in vivo with a specific activity comparable with natural bovine osteogenic protein and stimulates osteoblast proliferation and differentiation in vitro. J. Biol. Chem. 267 : 20352 20362, 1992.

31) Yamaguchi, A., Katagiri, T., Ikeda, T., Wozney, J. M., Rosen, V., Wang, E. A., Kahn, A. J., Suda, T. and Yoshiki, S. : Recombinant human bone morphogenetic protein-2 stimulates osteoblastic maturation and inhibits myogenic differentiation in vitro. J. Cell Biol. $113: 681 \sim 687,1991$.

32) Kodama, H., Amagai, Y., Sudo, H., Kasai, S. and Yamamoto, S.: Establishment of a clonal osteogenic cell line from newborn calvaria. Jpn. J. Oral Biol. 23 : 899 901, 1981.

33) Sudo, H., Kodama, H., Amagai, Y., Yamamoto, S. and Kasai, S. : In vitro differentiation and calcification in a new clonal osteogenic cell line 
derived from newborn mouse calvaria. J. Cell Biol. 96 : 191 198, 1983.

34) Kuboki, Y., Kudo, A., Mizuno, M. and Kawamura, $M$ : Time-dependent changes of collagen crosslinks and their precursors in the culture of osteogenic cells. Calcif. Tissue Int. $50: 473 \sim 480$, 1992.

35) Berry, L., Grant, M. E., McClure, J. and Rooney, P.: Bone-marrow-derived chondrogenesis in vitro. J. Cell Sci. $101: 333 \sim 342,1992$.

36) Benett, J. H., Joyner, C. J., Triffitt, J.T. and Owen, M.E. : Adipocytic cells cultured from marrow have osteogenic potential. J. Cell Sci.
99: 131 139, 1991.

37) Asahina, I., Sampath, T. K., Nishimura, I. and Hauschka, P. V.: Human osteogenic protein-1 induces both chondroblastic and osteoblastic differentiation of osteoprogenitor cells derived from newborn rat calvaria. J. Cell Biol. 123 : 921 933, 1993.

38) Rickard, D. J., Sullivan, T. A., Shenker, B. J., Leboy, P. S. and Kazhdan, I. : Induction of rapid osteoblast differentiation in rat bone marrow stromal cell culture by Dexamethasone and BMP-2. Dev. Biol. 161 : 218 228, 1994. 